\title{
OBITUARY
}

\section{Lothar Bohm}

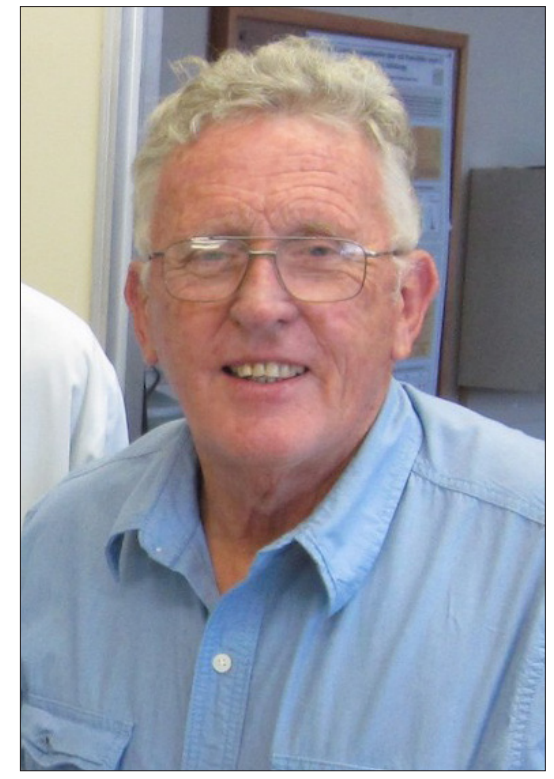

Lothar Bohm was Head and Associate Professor of Radiobiology at Stellenbosch University from 1980 to his retirement in 2002. The following are a few highlights of his illustrious career.

1969: $\mathrm{PhD}$ on mechanisms of calcium carbonate deposition in reef organisms under T F Goreau, University of the West Indies.
1976: DFG guest fellow, Kiel University (G Wefer), measuring calcification rates and reef productivity in defined biotopes.

1969 - 1976: Lecturer in biochemistry under C von Holt, University of Cape Town. Studied structure function relationships of histones, influence of polyelectrolyte shielding on histone aggregation and hydrodynamic behaviour, commercially applied to histone fractionation by gel exclusion (Boehringer).

From 1978: EMBO fellow, Biophysics Group of C Crane-Robinson, University of Portsmouth. Used histone peptides and nuclear magnetic resonance to identify sequences required for histone-histone interactions in histone oligomers and use of limit digestion to further delineate domain boundaries. RBE studies to examine the effectiveness of high-energy neutrons for use in tumour therapy. Evaluation of methylxanthines on cell cycle progression, repair inhibition and tumour oxygenation. In association with the research group of C Streffer (Essen), led an intercomparison of the clinical merits of high- and low-energy neutrons. Work with J Gueulette (Louvain) at the South African cyclotron addressed the tissue depth characteristics of $200 \mathrm{MeV}$ protons. As visiting fellow at KfA Julich in the laboratory of Ludwig Feinendegen, studied the influence of histone acetylation on DNA repair. In a long-standing co-operation with Friedrich Zywietz, University Klinikum Hamburg, evaluated cellular and systemic effects of pentoxifylline on tumour oxygenation, tumour control and radiobiological effectiveness.

Committee memberships: IAEA (Joloyn Hendry) on the clinical effectiveness of dose-modifying drugs and promotion of radiobiology and radiation oncology in Africa.

Grants: Volkswagenstiftung and Hoechst Pharmaceuticals, National Research Foundation, South African Medical Research Council, Cancer Association of South Africa, Harry Crossley and Becker Trust.

Chair: South African Radiobiology Society, 1998 - 2002.

Lothar is survived by his wife Anne (Basson) and children from a previous marriage, twins Been and Axel and a daughter Marlies.

\section{Ben Smit}

Cape Town, South Africa

ben_smit@vodamail.co.za 